\title{
Colgajo frontal. Método sencillo en la reconstrucción de defectos cutáneos nasales extensos
}

\author{
Forehead flap. A simple method for the reconstruction of extensive nasal skin \\ defects
}

R. González-García, L. Navas-Gías, F.J. Rodríguez-Campo, J. Sastre-Pérez

\begin{abstract}
Resumen: Las aplicaciones del colgajo frontal en la cirugía de los defectos nasales son destacables, pues la práctica totalidad de las sub-unidades nasales, incluidos el vestíbulo nasal, el reborde alar y la columela pueden ser reconstruidos satisfactoriamente. Su técnica de tallado es sencilla y las complicaciones de la zona donante escasas. El color de la piel, su textura y la posibilidad de obtener una amplia cantidad de tejido, con o sin expansión tisular previa, lo hacen de primera elección en la reconstrucción de defectos cutáneos nasales extensos. Referimos muestra experiencia reciente en el uso de este colgajo y revisamos el estado del arte actual en el empleo del mismo.
\end{abstract}

Palabras clave: Colgajo frontal, defecto nasal.

Recibido: 15.11 .06

Aceptado: 28.01 .09

\begin{abstract}
The use of the forehead flap in the surgery of nasal defects is noteworthy because almost all of the nasal subunits, including the nasal vestibule, alar margin, and columella nasi can be reconstructed satisfactorily. The cutting technique is simple and there are few donor zone complications. The color of the skin, its texture, and the feasibility of obtaining a large amount of tissue, with or without previous tissue expansion, make forehead flaps the technique of choice in the reconstruction of extensive nasal skin defects. We report our recent experience with this flap and we review the current state-of-the-art in the use of this flap.
\end{abstract}

Key words: Forehead flap, nasal defect. 


\section{Introducción}

La reconstrucción cutánea nasal tras resección oncológica con afectación importante de partes blandas supone un importante reto para el cirujano maxilofacial, el otorrinolaringólogo y el cirujano plástico. No en vano la nariz es el resultado de la combinación de sub-unidades convexas y cóncavas, separadas por crestas y valles, en equilibrio simétrico. ${ }^{1}$

Históricamente fue utilizado por Susruta Samhita en el año 700 a.C. Por esta razón actualmente se lo conoce como colgajo indio. Kazanjian ${ }^{2}$ y Converse $^{3}$ popularizaron este colgajo con una base ancha. Sucesivas mejoras fueron aplicadas al colgajo frontal, como la realización de extensiones laterales, ${ }^{4}$ el cierre primario de la zona donante ${ }^{2}$ o el diseño de las incisiones por debajo del reborde orbitario. 5

Es fundamental considerar inicialmente el tamaño del defecto y su localización precisa. De modo ideal deben buscarse una función y estética adecuadas. En defectos cutáneos nasales extensos mayores de $50 \%$, se recomienda el uso del colgajo que presentamos, por su textura y color similares y por la amplia superficie cutánea disponible. Referimos una muestra de pacientes con defectos cutáneos nasales extensos secundarios a resección oncológica, que fueron sometidos a cirugía reconstructiva mediante el empleo del colgajo frontal.

\section{Material y métodos}

Se recoge una muestra de 6 pacientes (Figs. 1-4) diagnosticados de neoplasia en la región nasal y a los que se realizó resección de la tumoración y reconstrucción mediante colgajo frontal. De los seis pacientes, 5 fueron varones y 1 mujer, con edades comprendidas entre los 71 y los 87 años, con una media de 77,16 años. Los diagnósticos fueron: carcinoma epidermoide de la piel nasal en 2 casos, epitelioma basocelular en 3 casos y melanoma de mucosa nasal con infiltración de piel en el último caso. El periodo de seguimiento de la serie varía entre los 6 meses y los 8 años, con una media de 4,91 años. Todos los pacientes se encuentran vivos sin signos de recidiva locorregional en el momento actual. Dos de los pacientes fueron sometidos a expansión cutánea de la región frontal previa al tallado del colgajo. Además de la expansión se empleó una modificación del diseño clásico del colgajo frontal mediano, por medio de una base ancha, con aprovechamiento de gran parte de la superficie cutánea de la frente.

El colgajo frontal, como fue descrito originalmente, está basado en ambas arterias supratrocleares y en el flujo de una colateral de la arteria facial. En ocasiones incluye la arteria supraorbitaria para mejorar la viabilidad del colgajo. El pedículo puede ser estrechado y extenderse por debajo del reborde orbitario para facilitar la llegada del mismo a la punta nasal. El empleo de eco-Doppler localiza la arteria supratroclear con gran precisión, generalmente en su salida a nivel del reborde orbitario superointerno. Se eleva el colgajo cutáneo frontal junto con el músculo frontal, en un plano superficial al periostio. Cuando el levantamiento del colgajo se encuentra a 1 ó $2 \mathrm{~cm}$ del reborde orbi-

\section{Introduction}

Reconstruction of the skin of the nose after oncologic resection with major soft tissue involvement is an important challenge for the maxillofacial surgeon, otorhinolaryngologist, and plastic surgeon. The nose, with its combination of convex and concave subunits separated by crests and valleys in symmetrical balance is an extremely problematic area. ${ }^{1}$

Historically, the forehead flap was used by Susruta Samhita in 700 b.c. For that reason, it is now known as the Indian flap. Kazanjian ${ }^{2}$ and Converse ${ }^{3}$ popularized this widebased flap. Successive improvements have been made in the forehead flap, such as the addition of lateral extensions, ${ }^{4}$ primary closure of the donor zone, ${ }^{2}$ or in the design of the incisions under the orbital rim. ${ }^{5}$

It is fundamental to begin by assessing the size of the defect and its exact location. Ideally, proper function and aesthetics should be sought. In extensive nasal skin defects of more than 50\%, the use of the flap described here is recommended, due to its similar texture and color and the large skin surface available. We report a sample of patients with extensive nasal skin defects secondary to oncologic resection who underwent reconstructive surgery using a forehead flap.

\section{Material and methods}

A sample of 6 patients (Figs. 1 to 4) diagnosed of neoplasm in the nasal region was collected in which tumor resection and reconstruction were made by means of a forehead flap The 6 patients, 5 men and 1 woman, had ages ranging from 71 to 87 years, mean 77.16 years. The diagnoses were squamous-cell carcinoma of the nasal skin in 2 cases, basal cell carcinoma in 3 cases, and melanoma of the nasal mucosa with skin infiltration in the last case. The follow-up period of the series ranges from 6 months to 8 years, with a mean of 4.91 years. All the patients are alive without signs of local or regional recurrence at time of writing. Two of the patients underwent cutaneous expansion of the forehead region prior to harvesting the flap In addition to expansion, a modification of the classic wide-based medial forehead flap design was used, taking advantage of the large skin surface of the forehead.

The forehead flap, as described originally, is based on both supratrochlear arteries and a collateral of the facial artery. Sometimes the supraorbital artery is included to enhance flap viability. The pedicle can be narrowed and extended below the orbital rim to facilitate flap transfer to the nasal tip. Doppler ultrasonography can be used to locate the supratrochlear artery accurately, generally at the point of exit at the level of the upper inner orbital rim. The forehead skin flap is lifted with the frontal muscle in a plane superficial to the periosteum. Once flap lifting comes to within 1 or $2 \mathrm{~cm}$ of the orbital rim, blunt dissection proceeds care- 


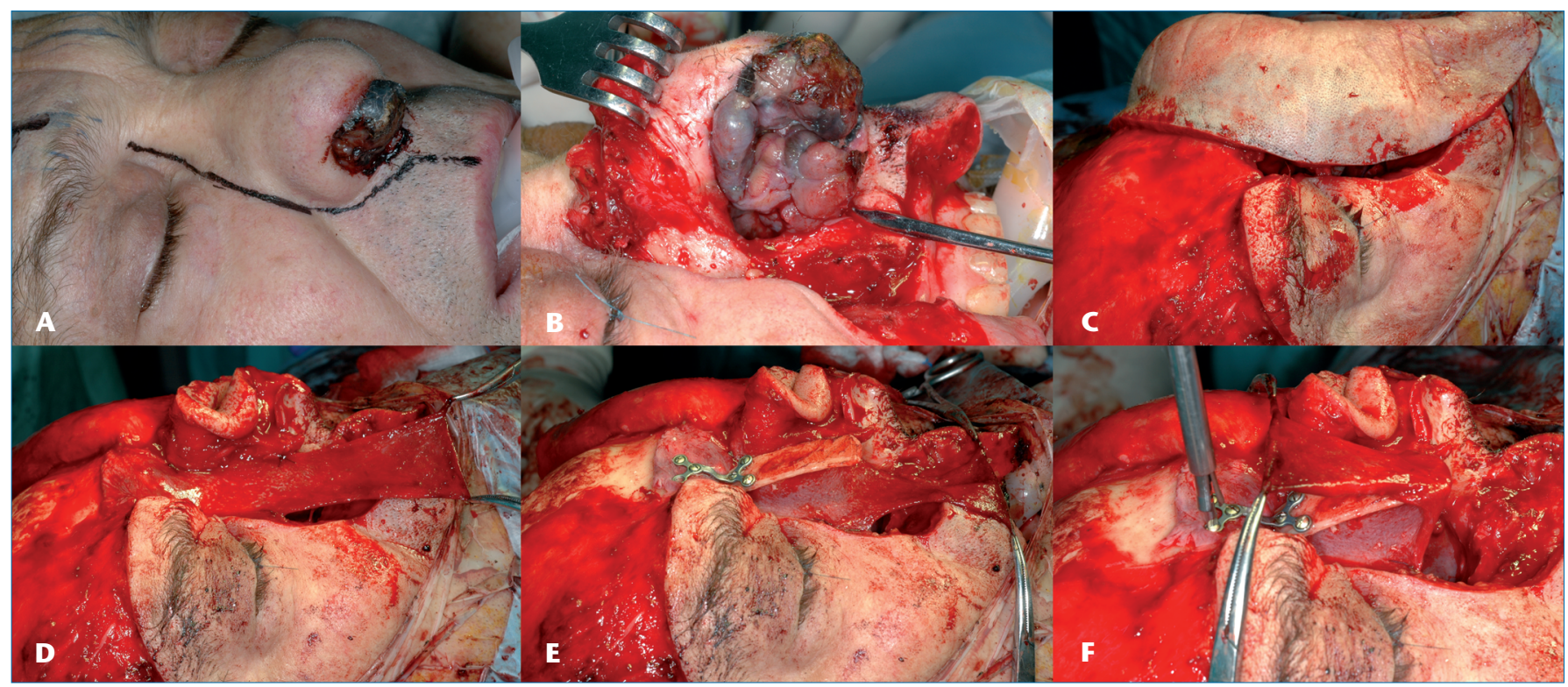

Figura 1. A. Paciente 1. Melanoma de la mucosa nasal. Vista preoperatoria. B. Resección de la lesión mediante abordaje de Weber-Ferguson. C. Trasposición de colgajo frontal amplio a la región nasal. D. Tallado de colgajo de galea para recubrimiento de injerto óseo de calota en la reconstrucción nasal. E. Fijación de injerto de tabla externa de calota mediante miniplaca, en la reconstrucción de dorso nasal. F. Cobertura del injerto óseo con colgajo de galea.

Figure 1. A. Patient 1. Melanoma of the nasal mucosa. Preoperative view. B. Resection of the lesion by way of a Weber-Ferguson approach. C. Broad transposition of the forehead flap to the nasal region. D. Cutting a galea flap to cover a skull bone graft in nasal reconstruction. E. Attachment of a graft of the external table of the skull by miniplate in the reconstruction of the dorsal nose. F. Coverage of the bone graft with a galea flap.

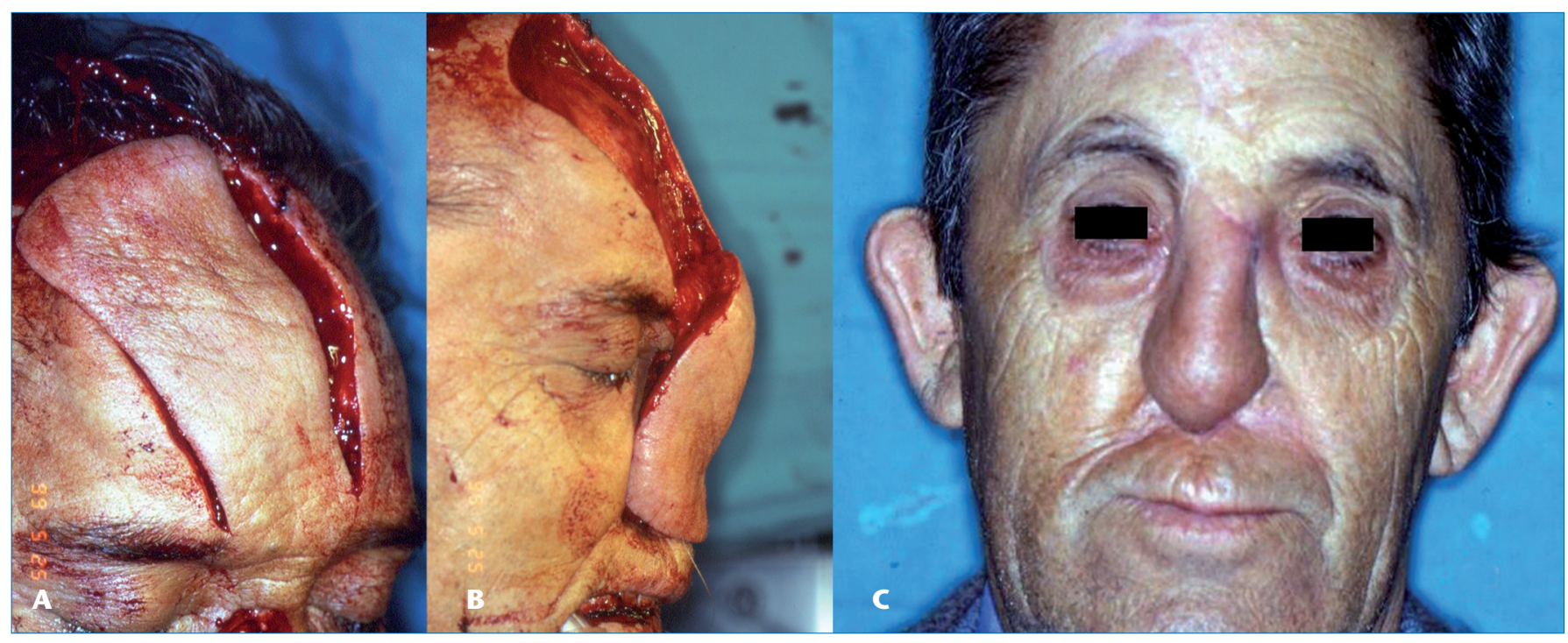

Figura 2. Paciente 2. Carcinoma epidermoide de piel en dorso y punta nasales. A. tallado del colgajo frontal. B. Cobertura de dorso y punta nasales. C. Resultado final.

Figure 2. Patient 2. Squamous-cell carcinoma of the skin of the dorsal nose and tip. A. Cutting of the forehead flap. B. Coverage of the dorsal nose and nasal tip. C. Final result.

tario se realiza disección roma cuidadosa hasta identificar la arteria supratroclear. Finalizado el levantamiento del colgajo, este se rota $180^{\circ}$ en su base y se cubre el defecto nasal con la parte distal del colgajo. El colgajo puede ser adelgazado a nivel de los tres cuartos distales, resecando músculo frontal y tejido graso subcutáneo. fully until the supratrochlear artery is identified. When the flap has been completely lifted, it is rotated $180^{\circ}$ on its base and the nasal defect is covered with the distal part of the flap. The distal three-fourths of the flap can be thinned by resecting the frontal muscle and subcutaneous adipose tissue. 

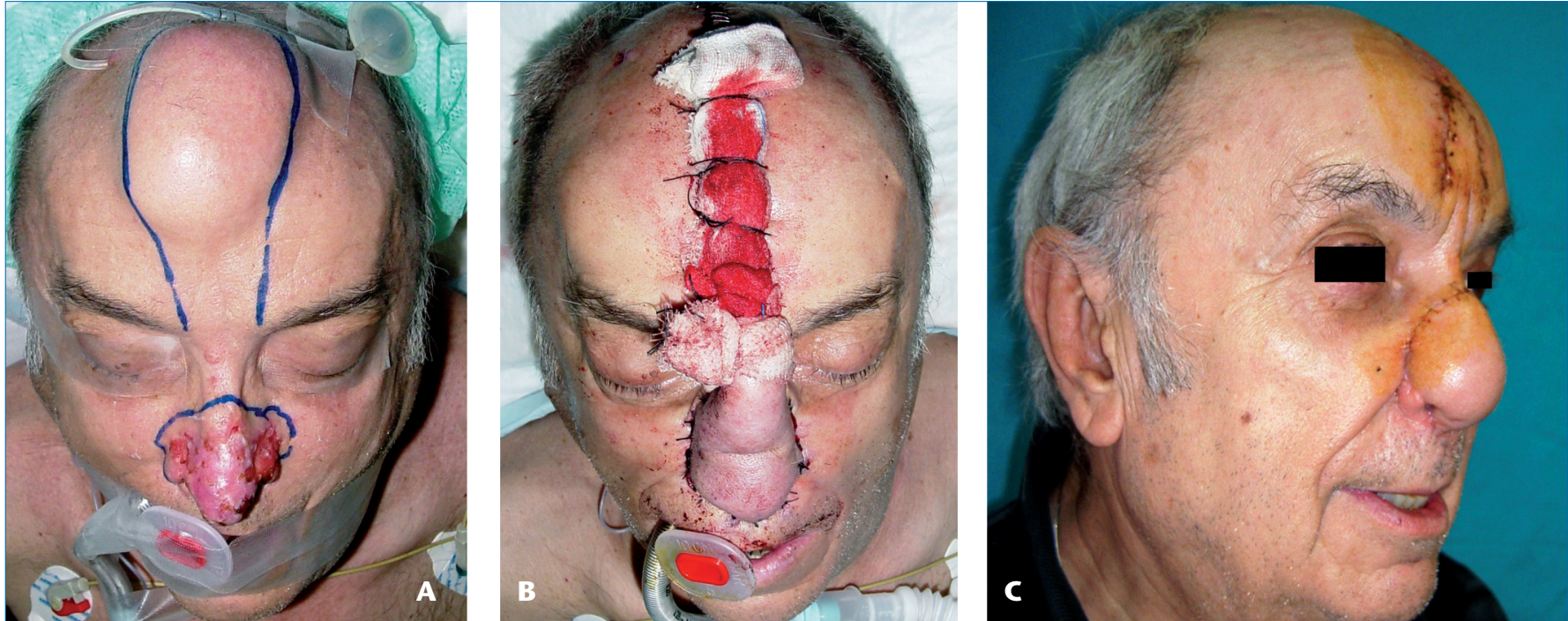

Figura 3. Paciente 3. Carcinoma basocelular de dorso y punta nasales. A. Expansión cutánea previo a tallado de colgajo frontal. B. Aspecto tras tallado del colgajo y reconstrucción nasal en el postoperatorio inmediato. C. Aspecto en el postoperatorio inmediato, previo a cirugía de adelgazamiento del colgajo.

Figure 3. Patient 3. Basal-cell carcinoma of the dorsal nose and nasal tip. A. Skin expansion before cutting the forehead flap. B. Aspect after cutting the flap and nasal reconstruction in the immediate postoperative period. C. Appearance in the immediate postoperative period, before flap thinning surgery.

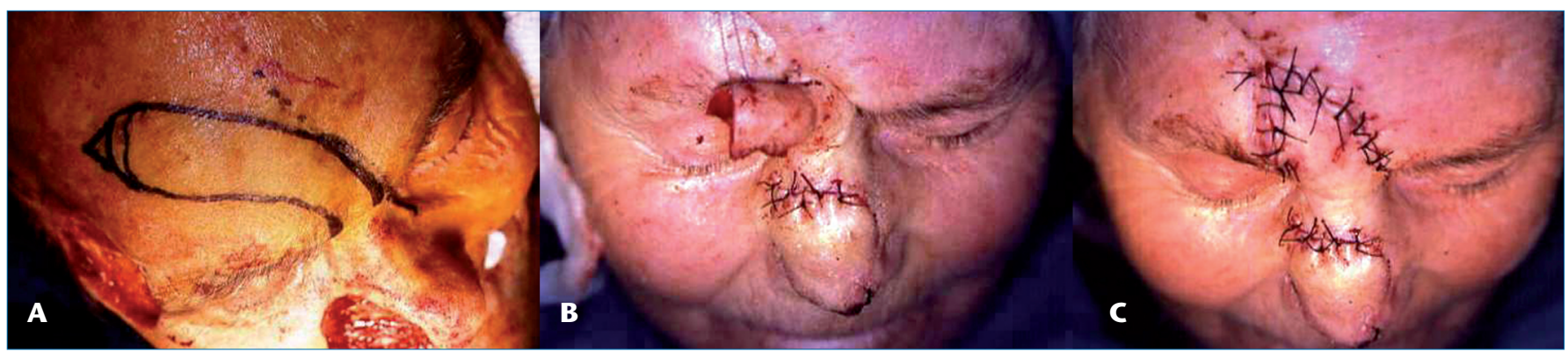

Figura 4. Paciente 4. Carcinoma basocelular de dorso y punta nasal. A. Diseño del colgajo frontal en su variante oblicua. B. Sección del pedículo en el segundo tiempo quirúrgico. C. Restitución de la parte proximal del colgajo a nivel de la zona donante.

Figure 4. Patient 4. Basal-cell carcinoma of the dorsal nose and nasal tip. A. Design of the forehead flap, oblique variant. B. Section of the pedicle in the second surgical intervention. C. Restoration of the proximal part of the flap at the level of the donor zone.

\section{Discusión}

Las sub-unidades nasales quedan definidas mediante la observación directa del contorno, textura y color nasales. Este concepto fue propuesto originalmente por Burget y Menick en 1985,6 y hace referencia a 9 divisiones: 5 convexas (punta, dorso, columella y dos alas nasales) y 4 cóncavas ( 2 triángulos de tejido blando y 2 paredes laterales nasales). La localización de las incisiones en los límites de estas sub-unidades facilita el camuflaje de las cicatrices y la contracción de estas aumenta la proyección de la subunidad reconstruida. La adhesión a este principio ha ganado popularidad, pero puede obviarse en los pacientes con fototipos I y II de Fitzpatrick, en los pacientes con pieles sebáceas o de textura muy suave y en aquellos con gran daño actínico. En estos casos las incisiones pueden situarse en el interior de las sub-unidades nasales ya que las cicatrices quedarán muy camufladas.

\section{Discussion}

The subunits of the nose are defined by direct observation of the nasal contour, texture, and color. This concept was proposed originally by Burget and Menick in 19856 and results in 9 divisions: 5 convex (tip, dorsum, columella nasi, and two alar cartilages) and 4 concave (2 triangles of soft tissue and 2 nasal lateral walls). Positioning the incisions at the limits of these sub-units helps to camouflage the scars and scar contraction increases the projection of the reconstructed subunit. Adherence to this principle has gained acceptance, but it can be avoided in patients with Fitzpatrick phototypes I and II, sebaceous skin, very smooth-textured skin, and in patients with intense actinic damage. In these cases, the incisions can be positioned inside the nasal subunits because the scars will be well camouflaged. 
Como en otro tipo de colgajos pediculados, uno de los inconvenientes del colgajo frontal es la necesidad de realizar un segundo tiempo quirúrgico. En nuestra experiencia la separación del pedículo a las 3 semanas es tiempo habitualmente suficiente, aunque hemos observado un caso de defecto parcial en la revascularización a partir de las zonas receptoras. En esta situación es preferible esperar otras tres semanas antes de la sección definitiva del pedículo. Esta opinión concuerda con el hallazgo de excelentes resultados en un paciente del grupo de Yoon, ${ }^{1}$ en el que la resección del pedículo se produjo 8 meses tras la cirugía reconstructiva, debido a la concurrencia de otros factores médicos. Por supuesto, por razones estéticas y sociales, la demora no es tan grande de modo habitual.

En relación a la anchura del colgajo, hemos conseguido el cierre primario directo sin tensión con anchuras de hasta $4 \mathrm{~cm}$. No obstante, debemos recordar que parte del pedículo será repuesto en la región glabelar y frontal, para proporcionar una distancia interpalpebral normal y conseguir un cierre más adecuado de la zona donante $y$, por tanto, no es necesario el cierre primario directo de la zona donante en toda su longitud. En este sentido y, para permitir una mejor aproximación de los bordes cutáneos en la zona donante y posibilitar el cierre primario, sugerimos la posibilidad de realizar incisiones verticales a nivel de la galea aponeurótica. En ocasiones es preciso un despegamiento extenso hacia ambas regiones temporales. La utilización de expansión cutánea previa obviará la necesidad de generar defectos muy extensos en la zona donante. No obstante, ante la imposibilidad de cierre primario, el cierre por segunda intención de parte de la zona donante no suele producir cicatrices aberrantes. En cualquier caso, una de las principales desventajas del colgajo frontal paramediano es la cicatriz vertical y todos los esfuerzos del cirujano deben centrarse en el cierre de la herida sin tensión. El colgajo frontal mediano, sin embargo, deja la cicatriz vertical en el centro y confiere un mejor resultado estético, en connivencia con los postulados de las unidades estéticas. Los pacientes con una línea de implantación capilar baja pueden beneficiarse de algunas modificaciones como el diseño oblicuo del colgajo frontal, la expansión tisular o la extensión del colgajo en el cuero cabelludo con posterior adelgazamiento y exclusión de folículos pilosos o depilación laser.7 Furuta et al, 8 han referido la posibilidad de reconstrucción nasal completa con un colgajo frontal dual expandido previamente.

El mayor grosor de la piel frontal ha sido señalado como un inconveniente a la hora de reproducir adecuadamente los contornos del esqueleto cartilaginoso nasal. Con el objeto de paliar esta situación, se ha propuesto el levantamiento supramuscular del colgajo, el adelgazamiento in situ antes de transponerlo y el adelgazamiento en un periodo intermedio antes de la sección definitiva del pedículo. ${ }^{8}$ Todas estas opciones son igualmente válidas. No obstante, en nuestra opinión, parece razonable posponerlo a un tercer tiempo quirúrgico, 3 meses después de la cirugía de sección del pedículo. En todo caso, los procesos de adelgazamiento in situ o en el periodo intermedio deberían realizarse con cuidado extremo, por la posibilidad de daño vascular asociado. Tradicionalmente se ha venido empleando el colgajo frontal pediculado a la arteria supratroclear contralateral al defecto nasal a reconstruir. Con la localización más precisa de la misma mediante Doppler es posible estrechar el pedículo minimizando los riesgos de lesión arterial. Esto faci-
As in other types of pediculated flaps, one of the disadvantages of the forehead flap is the need for a second surgical intervention. In our experience, it usually suffices separate the pedicle at 3 weeks, although we have observed a case of partial defect in the revascularization from the receptor zones. In such situations it is preferable to wait another three weeks before definitively sectioning the pedicle. This opinion coincides with the excellent results found in a patient of the Yoon group,$^{1}$ in which the pedicle was resected 8 months after reconstructive surgery, due to the concurrence of other medical factors. Naturally, for aesthetic and social reasons, the delay is usually not as long.

In relation to flap width, we achieved direct primary closure without tension using widths of up to $4 \mathrm{~cm}$. However, we must remember that part of the pedicle will be replaced in the glabellar and forehead region to establish a normal distance between eyelids and to better close the donor zone. Direct primary closure of the entire length of the donor zone is not necessary. In this sense, to enable better approximation of the skin edges in the donor zone and to make primary closure possible, we suggest that vertical incisions be made at the level of the aponeurotic galea. Sometimes it is necessary to lift the tissue extensively toward the two temporal regions. The use of previous skin expansion will avoid the need for creating extensive defects in the donor zone. However, given the impossibility of primary closure, closure of part of the donor zone in a second intervention usually does not produce aberrant scars. In any case, one of the main disadvantages of the paramedial forehead flap is the vertical scar. The surgeon must make a concerted effort to close the wound without tension. The medial forehead flap, however, leaves a vertical scar in the center and produces a better aesthetic result, according to the postulates of cosmetic surgery. Patients with a low hairline may benefit from some modifications, such as an oblique forehead flap design, tissue expansion, or extension of the flap into the scalp followed by thinning and elimination of the hair follicles or laser depilation. ${ }^{7}$ Furuta et al. ${ }^{8}$ have reported the alternative of complete nasal reconstruction with previously expanded dual forehead flaps.

The greater thickness of the forehead skin has been cited as a disadvantage for properly reproducing the contours of the nasal cartilaginous skeleton. Supramuscular flap elevation has been proposed as a way of palliating this situation prior to intermediate-term transposition and thinning in situ before definitively sectioning the pedicle. ${ }^{8}$ All of these options are equally valid. However, in our opinion it seems reasonable to postpone sectioning the pedicle for a third surgical intervention 3 months after surgery. In any case, the processes of thinning in situ or in the intermediate term should be done with extreme care due to the possibility of associated vascular damage. Traditionally, a pediculated forehead flap of the supratrochlear artery on the opposite side of the nasal defect to be reconstructed has been used. By more exactly locating the artery by Doppler ultrasonography, the 
lita la rotación del pedículo sin aumentar el riesgo de torsión y, por lo tanto, se pueden alcanzar defectos nasales ipsilaterales con relativa facilidad. En los casos en los que existen defectos de gran tamaño, puede emplearse gran parte de la superficie cutánea frontal. Con este diseño, la anchura del colgajo puede superar los $4 \mathrm{~cm}$ señalados con anterioridad. En estos casos, la rotación puede ser más difícil $y$, en ocasiones, es preciso realizar una pequeña sección a nivel de la zona medial del pedículo. Esta maniobra permite una rotación suficiente para llegar a la punta nasal, mientras la vascularización se asegura por medio de la arteria supraorbitaria. No observamos problemas de vascularización en los dos pacientes en los que realizamos esta modificación.

Las posibilidades reconstructivas que ofrece este colgajo son importantes ya que prácticamente todas las sub-unidades nasales pueden ser reconstruidas, incluidos el vestíbulo nasal, el reborde alar y la columela. Se ha referido para defectos alares mayores de $1,5 \mathrm{~cm}$ y para defectos mayores de $2,5 \mathrm{~cm}$ que afecten cualquier subunidad nasal o defectos que involucren varias sub-unidades nasales. ${ }^{1}$ Converse y Word-Smith ${ }^{9}$ describieron el colgajo frontal en isla, mediante el cual realizaban la reconstrucción nasal en un solo tiempo quirúrgico. La técnica consiste en la esqueletización de la arteria supratroclear contralateral al defecto nasal y la tunelización del colgajo en su base por debajo de la piel nasal. Lo utilizaron para defectos de la pared nasal lateral y dorso, pero no en defectos alares o de la punta nasal. El principal inconveniente de esta variante es la mayor probabilidad de congestión venosa por compresión del pedículo en la región glabelar. Otros autores, sin embargo, no han observado estos problemas. ${ }^{10}$

Creemos fundamental la reconstrucción ad integrum de los defectos nasales generados tras la resección oncológica. En este sentido encontramos casos en el que el revestimiento cutáneo es suficiente para una reconstrucción nasal satisfactoria, pues es posible la conservación del esqueleto óseo-cartilaginoso nasal subyacente. Otros casos, sin embargo, precisarán la utilización de injertos óseos, de cartílago y restitución del revestimiento mucoso, además de la cobertura cutánea. Proponemos el empleo de injerto óseo de tabla externa de calota fijada mediante miniplacas a la región glabelar del hueso frontal y su revestimiento por medio de un segmento de colgajo de galea con pedículo inferior plegado sobre el segmento óseo a nivel del neo-dorso nasal. Dos de los casos presentados fueron reconstruidos de este modo.

La región de las narinas es siempre compleja en su estructura y por tanto difícil de remedar en ausencia de cartílagos alares. Aunque el resultado estético es discreto, el pliegue del colgajo de piel sobre sí mismo en su extremo distal permite alcanzar una solución aceptable. Pese a la posibilidad de conservar intacta parte de la estructura nasal del paciente, en ocasiones cabe plantearse como mejor opción la resección completa, sobre todo cuando con la primera posibilidad pueda generarse una alteración importante de las sub-unidades nasales. En definitiva, podemos esperar reconstrucciones más simétricas cuando el defecto nasal es total ya que la preservación del ala nasal contralateral al defecto puede ser difícil de remedar con la piel del colgajo.

De otra parte, podemos emplear expansores titulares colocados en el tejido subcutáneo de la región frontal en defectos de gran tamaño o en pacientes multi-intervenidos en los que no es posible otro tipo de reconstrucción por excesiva tensión de los tejidos. En un segun- pedicle can be narrowed, thus diminishing the risks of arterial injury. This facilitates the rotation of the pedicle without increasing the risk of torsion and, consequently, same side nasal defects can be repaired with relative ease. In cases in which large defects exist, much of the skin surface of the forehead can be used. With this design, the width of the flap can be more than the $4 \mathrm{~cm}$ indicated above. In these cases, the rotation can be more difficult and, on occasions, a small section has to be made at level of the medial pedicle. This maneuver allows enough rotation to bring the flap to the tip of the nose, while vascularization is ensured by the supraorbital artery. We did not observe problems of vascularization in the two patients in which this modification was used.

The reconstructive possibilities of this flap are important because practically all the nasal subunits can be reconstructed, including the nasal vestibule, the alar edge, and the columella nasi. It has been recommended for alar defects of more than $1.5 \mathrm{~cm}$, for defects of more than $2.5 \mathrm{~cm}$ that affect any nasal subunit, or for defects that involve several nasal sub-units. ${ }^{1}$ Converse and Word-Smith 9 reported an island forehead flap by means of which they performed nasal reconstruction in a single surgical time. The technique consists of skeletonization of the supratrochlear artery on the side opposite the nasal defect and tunneling the base of the flap below the nasal skin. It was used for defects of the lateral wall and dorsal nose, but not for defects of the alae or nasal tip. The main drawback to this variant is a greater probability of venous congestion due to pedicle compression in the glabellar region. Other authors, however, have not observed these problems. ${ }^{10}$

We consider reconstruction ad integrum of the nasal defects produced by oncologic resection to be mandatory. With regard to this point, we find cases in which the skin covering is sufficient for a satisfactory nasal reconstruction because the underlying nasal bone and cartilage structure can be conserved. Other cases, however, will require the use of bone grafts, cartilage, and restoration of the mucosal layer, in addition to the skin covering. We propose the use of a bone graft of the external table of the skull attached by means of miniplates to the glabellar region of the frontal bone, covered over by means of a segment of galea flap with the lower pedicle folded over the bone segment at the level of the new dorsal nose. Two of the cases presented here were reconstructed in this way.

The region of the nostrils is always complex in structure and difficult to imitate in the absence of alar cartilages. Although the aesthetic result was merely discrete, folding the skin flap over itself at the distal end allows an acceptable solution to be reached. Despite the possibility of conserving part of the patient's nasal structure intact, sometimes complete resection is a better option, particularly when an important abnormality of the nasal subunits is generated with the first option. We can expect to achieve more symmetrical reconstructions when the nasal defect is total because the preservation of the contralateral nasal alar cartilage 
do tiempo quirúrgico, se retira el expansor y se talla el colgajo frontal sobre el tejido expandido. La utilización de expansores cutáneos como opción quirúrgica en la reconstrucción de defectos craneofaciales ha sido evaluada por nuestro grupo con anterioridad. ${ }^{11}$ La morbilidad de la zona donante es mínima, con creación de cicatrices lineales libres de tensión y por tanto poco tendentes a dehiscencia. No observamos exposición del dispositivo de expansión, necrosis de la piel expandida ni dehiscencia de sutura en los dos casos en los que realizamos expansión tisular previa al tallado del colgajo frontal.

\section{Conclusiones}

En resumen, consideramos el colgajo frontal con sus diversas variantes, mediano, paramediano, con extensiones laterales y previa expansión tisular, una opción reconstructiva de primera línea en el tratamiento de defectos nasales cutáneos extensos. El empleo de técnicas de injerto óseo, cartílago y revestimiento interno a modo de neo-mucosa nasal es siempre deseable en defectos nasales totales, con afectación del esqueleto nasal subyacente. El respeto de las sub-unidades nasales es fundamental para una reconstrucción estética adecuada. Cuando la resección atraviesa la mitad de una subunidad nasal puede ser recomendable la restitución de toda la subunidad con tejido de similares características de textura y color como el colgajo frontal. Estas propiedades y la posibilidad de ofrecer una cobertura cutánea amplia lo hacen especialmente útil a la hora de remedar la punta nasal y la región cutánea de ambas alas nasales y vestíbulos.

\section{Bibliografía}

1. Yoon T, Benito-Ruiz J, García-Díez E, Serra-Renom JM. Our algorythm for nasal reconstruction. Plast Reconstr Surg 2006;59:239-47.

2. Kazanjian $\mathrm{VH}$. The repair of nasal defects with the median forehead flap: primary closure of the forehead wound. Surg Gynecol Obstet 1946;83:37-42.

3. Converse JM. New forehead flap for nasal reconstruction. Proc R Soc Med 1942;35: 811-2.

4. Millard DR. Reconstructive rhynoplasty for the lower two-thirds of the nose. Plast Reconstr Surg 1976;57:722-8.

5. Burget GC, Menick FJ. Nasal reconstruction: seeking a forth dimension. Plast Reconstr Surg 1986;78:145-57.

6. Burget GC, Menick FJ. The subunit principle in nasal reconstruction. Plast Reconstr Surg 1985;76:239-47.

7. Boyd CM, Baker SR, Fader DJ, Wang TS, Johnson TM. The forehead flap for nasal reconstruction. Arch Dermatol 2000;136:1365-70.

8. Burgueño García M, Arias Gallo J. Reconstrucción nasal. En: López-Cedrún JL. Cirugía reconstructiva y estética del tercio medio facial. Madrid. Arán Ediciones S.L, 2005;pp:118-27.

9. Converse JM, Word-Smith D. Experiences with forehead island flap. Clin Plast Surg 1963;31:521-37.

10. Park SS. Reconstruction of nasal defects larger than 1.5 centimeters in diameter. Laryngoscope 2000;110:1241-50.

11. Escorial Hernández V, Capote Moreno A, González-García R, Rodríguez Campo FJ, Naval Gías L, Díaz González FJ. Expansión tisular en la reconstrucción de defectos craneofaciales. Rev Esp Cirug Oral Maxilofac 2004;26:297-303. on the side opposite to the defect can be difficult to remedy with the skin flap.

On the other hand, we can place tissue expanders in the subcutaneous tissue of the forehead region in large defects or in patients who have been intervened more than once, in whom another type of reconstruction may not be possible due to excessive tension on the tissues. In a second surgical intervention, the expander is removed and the forehead flap is cut out of the expanded tissue. The use of skin expanders as a surgical option in the reconstruction of craniofacial defects has been evaluated by our group previously. ${ }^{11}$ The morbidity of the donor zone is minimal, and linear, tension-free scars with no tendency to dehiscence are created. We did not observe exposure of the expansion device, necrosis of the expanded skin, or suture dehiscence in either of the two cases in which we performed tissue expansion before harvesting the forehead flap.

\section{Conclusions}

In summary, we consider that the forehead flap with its diverse variants (medial, paramedial, lateral extensions, and tissue expansion) is a first-line reconstruction option in the treatment of extensive nasal skin defects. The use of bone graft techniques, cartilage, and an internal lining in the form of a nasal neo-mucosa is always desirable in total nasal defects with involvement of the underlying nasal skeleton. Respect for the nasal sub-units is the key to achieving a suitable aesthetic reconstruction. When the resection involves more than half of a nasal subunit, it may be advisable to restore the entire subunit with tissue of texture and color characteristics similar to the forehead flap. These properties and the possibility of obtaining ample skin coverage make the forehead flap especially useful when restoring the nasal tip and the skin region of both nasal alar cartilages and vestibules. 